\title{
İnsan biyolojik materyalinin araştırma amaçlı olarak kullanılması ile ilgili araştırmacı ve araştırma etik kurul sorumluluğu
}

\author{
Investigator and research ethics committee responsibility for the use of \\ human biological material for research purposes
}

\author{
Nüket BÜKEN*⿻
}

Hacettepe Üniversitesi Tıp Fakültesi, Tıp Etiği ve Tıp Tarihi Anabilim Dalı, Ankara/TÜRKiYE

\begin{abstract}
Öz
Laboratuvar hekimleri sıklıkla, kapasiteleri ölçüsünde yeteneklerine göre klinisyen, araştırmacı ve sağlık savunucusu olarak farklı roller oynamaktadır. Hastayla direkt temasta bulunmuyor olsalar da, "meçhul" laboratuvar hekimlerinin ilk ve en önemli görevi "yüzü bilinmeyen" ve sadece bir sayı ile ifade edilen hastası için, en uygun olanı, en doğru şekilde yapmak olacaktır. Laboratuvar hekimi hastayla ilgili kişisel bilgilere sahip olmasa da, hastanın en azından bir parçasıyla yakın temastadır, biyolojik örnekle güçlü bir ilişki kurulmuştur ve dolayısıyla bu alışılmadık sözleşme klinisyen, laboratuvar hekimi ve biyolojik örneğin sahibi olan hasta arasında kurulmuştur.

Tıbbi ilerlemeler, her zaman insan bedenleri ve insan doku örnekleri kullanılarak gerçekleştirilen eğitim süreçlerine güvendi. Son yıllarda, insan organ, doku ve genetik materyallerinin Dünya çapında toplanması ve depolanması ile "insan doku arşivi" olarak bilinen, geniş kaynak ve sayısız önemli tıbbi buluşlar sağlanmıştır. Bu biyolojik arşivler araştırma kaynağı olarak kullanılmaya devam ettiği sürece insanlık ilerleyecektir.

Biyolojik materyallerin saklanmasındaki teknik olanakların gelişimi yanında, biyolojik verilerin dijital ortamda işlenmesi ve bilgisayar teknolojilerindeki yenilikler de örneklere ait verilerin toplanmasını, izlenmesini ve üzerinde her türlü analizin yapılmasını kolaylaştırmaktadır. Biyobankalar arasındaki veri akışının etkin bir biçimde yapılabilmesi, çok odaklı bilimsel araştırmaları kolaylaştıran bir etkendir ve bu nedenle ulusal ve uluslararası düzeyde biyobankaların belirli standartlara uygun olarak işlev görmeleri sağlanmaya çalışıımaktadır. Biyobankacılığın hızla gelişmesi ve giderek daha da karmaşık bir yapıya bürünmesi sonucunda bilinen temel etik konular dışında yeni etik sorunlarla da karşılaşılmaktadır.
\end{abstract}

Anahtar kelimeler: laboratuvar tıbbı; biyoetik; araştırma; insan biyolojik materyali; biyobanka; onam

Sorumlu Yazar*: Nüket Büken, Hacettepe Üniversitesi Tıp Fakültesi, Tıp Etiği ve Tıp Tarihi Anabilim Dalı, Ankara/TÜRKiYE E-posta: nuketbuken@hotmail.com

ORCID: 0000000191666569

Gönderim: 09.04.2018 Kabul: 28.05.2018

Doi:10.18663/tjcl.413878 


\begin{abstract}
Laboratory medicine physicians frequently play several roles in their capability as clinicians, investigators and health defender . Even though there is commonly no direct touch on patients, the "faceless" laboratory doctor's first and prominent task is to act in the best interests of the "faceless" patient who is frequently "just a number". Although individual information of the patient is often deficient, the laboratory doctor does have sincere knowledge of at minimum part of the patient -the specimen- and an unusual three-way contract is made between clinician, laboratory physician and patient.

Medical progress has always relied on learning from human bodies and human tissue samples. In recent years, human organs, tissue, and genetic material throughout the World have been collected and stored, and this vast resource, known as "the human tissue archive," has enabled countless crucial medical discoveries. It is essential that humankind continue to add to this archive and that it remain avaliable as a research resource.

The development of technical facilities in storage of biological materials as well as utulizing digital medium in processing biological data and innovations in the computer technology have made collection, monitoring and analysis of the data samples easier. Efficient data flow between the biobanks is a factor that facilitates multifocal scientific research. Therefore, biobanks / biolabs in both national and international level are aimed to function in accordance with specific standards. As a result of rapid development and increasingly complex structure of biobanking we have encountered in new ethical challenges besides the main ethical issues.
\end{abstract}

Keywords: laboratory medicine; bioethics; research; human biological material; biobanking; consent

\section{Giriş}

Günümüz tıbbı artık daha çok kişisel (personalized medicine), öngörülebilir, önleyici, hassas (precision medicine) ve bu alandaki bütün aktörlerin katılımını öngören bir anlayıştadır. Laboratuvar tıbbi da tıpkı klinik tıbbı gibi bu dönüşüme büyük katkı sağlamaktadır ve gelecekte çok daha etkin bir rol oynama potansiyeline sahiptir. Özellikle insan biyolojik materyalleri üzerinde yapılan laboratuvar çalışmaları ve elde edilen verilerin disiplinlerarası ve çok uluslu araştırmalarda kullanımı, ülkeler için önemli sonuçlar içerme potansiyeline sahip olmaları nedeniyle, hükümetler tarafından da giderek daha çok desteklemektedir.

Günümüzde biyotıp teknolojileri, yalnızca tanı-tedavi sürecini değil, biyotıp araştırmalarının niteliğini ve bu süreçte sınırları belirleyecek olan etikolegal düzenlemeleri değiştirmekte, dönüştürmektedir; gen editing teknolojileri, tüm genom sekanslama, genetik testler ve tesadüfi bulgular, tüketiciye verilen doğrudan genetik hizmetler (direct-to-consumer testing), insan embriyosunda genom biçimlendirme, süper insan, yapay zeka, özerk makineler, büyük veri (big data), robot teknolojileri etiği, embriyonun bilimsel araştırmalardaki kullanımı, yapay üreme teknolojilerinde babalık ve anneliğin yeni boyutunun tartışılmaya başlanması, bu teknolojilerin kötüye kullanılmasının öjeniye neden olabilmesi ya da insanın doğal kapasitesinin iyileştirilmesinin yol açacağı sorunlar... gibi.

Sağlık alanında hızlı bir şekilde kullanılmaya başlanan bu yeni ve gelişen teknolojiler toplumu karmaşık, belirsiz ve öngörü- lemez bir sürece dahil etmektedir. Bunun sebeplerinden biri bu teknolojilerin risk ve yan etkilerinin öğrenilmesinin, ancak tecrübe yolu ile mümkün olabilmesidir. Öte yandan, henüz güvenilirliği bilinmeyen teknolojilerin geliştirilmesi ve kullanılması ile ortaya çıkan biyoetik sorunlar da pek çoktur; gizlilik, mahremiyet, ayrımcılık, özerkliğe saygı, risklerin önlenmesi, bu teknolojilere eşit ve adil erişimin nasıl sağlanacağı... gibi.

Özellikle genetik araştırmalar, biyotıp araştırmaları ve biyoteknoloji alanındaki gelişmeler sonucunda, insan biyolojik materyali üzerindeki etik sorumlulukların ve hakların belirlenmesinde geleneksel etik yaklaşımların artık yetersiz kaldığı görülmektedir. Birkaç damla kan veya örneğin, KC dokusuna ait birkaç patolojik doku örneğinin, tek başına fazla bir değer taşımadığını ancak geniş bir koleksiyona dönüştürüldüğünde, önemli boyutta bilimsel ve ekonomik değere ulaşabildiğini artık biliyoruz. Hatta bu veriler, tıbbi kayıtlarla veya vericilerle ilgili başka kayıtlarla ilişkilendirildiğinde, bu değer daha da artmaktadır. Bu nedenle "biyolojik örnekler üzerindeki sahiplik hakları", "yararın paylaşımı", "gizliliğin ve mahremiyetin korunması", "patent hakkı" gibi konularda, yeni etik ve hukuksal sorunlar ortaya çıkmaktadır.

Çağımızda, yüksek teknoloji tıbbının hüküm sürdüğü biyotıp alanında, etkililik ve teknik yenilikler, yalnızca bilim insanlarının değil, hastaların ve toplumun da ilgisini üzerine toplamaktadır. Yüksek etik standartların hem klinik hem de laboratuvar çalışmalarında hayati önemi olmasına ve laboratuvar takiplerinde 
de etik ikilemlerle sık karşılaşılıyor olunmasına rağmen, laboratuvar uygulamalarında etik konusu ister tanı isterse araştırma ile ilgili olsun, günümüzde hak ettiği ilgiyi görmemektedir.

Özellikle patolojik/biyokimyasal değerlendirmelerde hem tanı/tedavi hem de araştırma uygulamalarında doğruluk, standartlara uygunluk çok önemlidir; hastayla direkt temasta bulunmuyor olsalar da laboratuvar hekimlerinin ilk ve en önemli görevi "yüzü bilinmeyen" hastası için en uygun olanı en doğru şekilde yapmak olacaktır. Laboratuvar hekimi hastayla ilgili kişisel bilgilere sahip olmasa da, hastanın en azından bir parçasıyla yakın temastadır, biyolojik örnekle güçlü bir ilişki kurulmuştur ve dolayısıyla genetik bilgiyi taşıyan biyolojik örneğin sahibi olan hastadan da sorumludur.

Hastayla direkt temasta bulunmuyor olsalar da, laboratuvar hekimlerinin (tıbbi biyolog, biyokimya uzmanı ve patologların) ilk ve en önemli görevi, "yüzü bilinmeyen” ve sadece bir doku veya hücresi ile var olan ve dosya sayısı ile ifade edilen hastası için, en uygun olanı, en doğru şekilde yapmak olacaktır. Laboratuvar hekimleri ve patologlar, hastayla ilgili kişisel bilgilere sahip olmasalar da, hastanın en azından bir parçasıyla yakın temastadırlar. Hastanın biyolojik örneğiyle güçlü bir ilişki kurulmuştur ve bu alışılmadık sözleşme; klinisyen, laboratuvar hekimi/patolog ve biyolojik örneğin sahibi olan hasta arasında kurulmuştur (1).

Tıbbi ilerlemeler, her zaman insan bedenleri ve insan doku örnekleri kullanılarak gerçekleştirilen eğitim süreçlerine güvendi. Son yıllarda, insan organ, doku ve genetik materyallerinin Dünya çapında toplanması ve depolanması ile "insan doku arşivi" olarak bilinen, geniş kaynaklara ve sayısız önemli tıbbi buluşlara imkân sağlanmıştır. Bu biyolojik arşivler araştırma kaynağı olarak kullanılmaya devam ettiği sürece de biyotıp araştırmaları ilerleyecektir.

Biyolojik materyallerin saklanmasındaki teknik olanakların gelişimi yanında, biyolojik verilerin dijital ortamda işlenmesi ve bilgisayar teknolojilerindeki yenilikler de örneklere ait verilerin toplanmasını, izlenmesini ve üzerinde her türlü analizin yapılmasını kolaylaştırmaktadır. Yani hem biyolojik materyalin kendisi, hem de bu materyalden elde edilen veriler önem kazanmaktadır. Bu materyaller her zaman bir biyobankada ve biyobankanın güvenlik koşullarında var olmayabilir; bir laboratuvar arşivi, patoloji arşivi şeklinde bireysel ya da kurumsal olarak oluşturulmuş olabilir. Bu durumda tanı ya da araştırma amaçlı olarak toplanan insan biyolojik materyallerinin toplanma amacı dışında kullanılması mümkün müdür? Araştırmacıyı, çalıştığı kurumu ve kurumun etik kurullarını bağlayıcı hükümler nelerdir? Söz konusu biyobankalar olduğunda belirlenen etikolegal sınırlar, bu tür durumlardaki sorunu çözmediğinde yapılması gerekenler nelerdir?

Biliyoruz ki, biyobankalar arasındaki veri akışının etkin bir biçimde yapılabilmesi, çok odaklı bilimsel araştırmaları kolaylaştıran bir etkendir ve bu nedenle ulusal ve uluslararası düzeyde biyobankaların belirli standartlara uygun olarak işlev görmeleri sağlanmaya çalışılmaktadır. Biyobankacılığın hızla gelişmesi ve giderek daha da karmaşık bir yapıya bürünmesi sonucunda bilinen temel etik konular dışında yeni etik sorunlarla da karşılaşılmaktadır. Bu konu ile ilgili ulusal literatür de oluşmaya başlamıştır. Ancak öte taraftan yine biliyoruz ki ülkemizde "biyobanka" olma koşullarını sağlayabilecek çok az sayıda örnek vardır; bu durumda, "biyobanka" olmayan, ama kişisel ya da kurumsal olarak "depolanmış biyolojik materyal içeren" arşivlerin durumu ne olacaktır? Özellikle patologlar, biyokimya uzmanları ve tıbbi biyologlar tarafından en sık sorulan soru da budur.

Hasta ile klinisyen hekim ve laboratuvar hekimi arasındaki ilişki, incelemesi yapılan biyolojik materyal üzerinden kurulmakta olup, ilgili tanı materyalinin o anda devam eden ya da gelecekte yapılması öngörülen herhangi bir araştırma amacıyla kullanımı konusu, laboratuvar hekimi sorumluluğuna, bir de "araştırmacı hekim sorumluluğu"nun eklenmesi anlamına da gelmektedir.

Laboratuvar tıbbı açısından, yapılacak tetkikler için aydınlatılmış onamın bulunduğundan emin olmak ve test sonuçlarını etik ve kanuni gereklilik veya toplum sağlığı açısından tersi gerekmedikçe, hastanın bakım çerçevesi dışına çıkarmamak zaten laboratuvar hekiminin sorumluluğudur (1).

Diğer taraftan, DNA'a ulaşımın ticari değerinin yüksek olduğu biyoteknoloji çağında, hastanın yapılması için izin vermemiş olduğu testlerin (tanısal amaçlı) yapılmasının uygun olmadığı ve yine sahiplerinin aydınlatılmış onamı alınmadan depolanmış dokuların/insan biyolojik materyallerinin araştırma amaçIı olarak kullanılmaması gerektiğinin kabul edilmesi ve göz önünde bulundurulması önemlidir.

Klinik teşhisi koyan klinisyen ile doku teşhisini koyan laboratuvar hekiminin arasındaki iletişimin niteliğinin önemi kadar, araştırmacı laboratuvar hekimi ile örneği veren hasta arasındaki iletişim de en az o kadar önemlidir. İnsan biyolojik verilerinin laboratuvar araştırmalarında araştırma materyali olarak kullanılması durumlarında, söz konusu bireylerin araştırma konusunda ayrıntılı bir biçimde (amacı, süresi, yararları, tehlikeleri...) bilgilendirilmeleri, aydınlatılmış onamlarının alınması, diledikleri zaman deneyden çekilme haklarının olduğu konusunda bilgilendirilmeleri önemlidir $(2,3)$. 


\section{Hasta Mahremiyeti Açısından Veri Güvenliğinin Sağlanması}

Bilgisayar teknolojileri ve dijital bilginin hayatımızın hemen her alanına girmiş olduğu günümüzde, mahremiyetin ve güvenliğin sağ $\neg$ lanması son derece önem kazanmaktadır. Sağlık kuruluşları/laboratuvarları ara $\neg$ sındaki ya da biyobankalar gibi tıbbi veri sağlayıcısı organizasyonlar arasındaki veri akışları, sağlık hizmetlerinin kalitesini ve araştırma olanaklarını artıırken hasta mahremiyetinin ihlal edilmesi riskini de arttırmaktadır $(2,3)$. İletişim teknolojilerinin biyotıp alanında kullanımının hızla yaygınlaşması pek çok açıdan kolaylıklar sağlarken, bu verilerin depolanması ve transferi konularında güvenlik ihtiyacını da gündeme getir $\neg$ mektedir. Gizliliğin korunmasında teknik önlemlerin alınması, iletişim kanalla-rının güvenliğinin sağlanması, verilerin anonimleştirmesi, kodlama veya dijital imza kullanılması alınacak önlemlerden bazılarıdır. Özellikle tıbbi kayıtların elektronik ortama dönüşümü, bu verilere yetkisiz erişilmesine karşı yeni koruma kalkanlarının geliştirilmesi gereğini doğurmaktadır.

Veri güvenliğinin sağlanmasında; verilerin kalitesini koruyacak sistemlerin geliştirilmesi, verilerin toplanma amaçları dışında kullanılamaması, veri-lere ilgilinin rızası olmadan ulaşılamaması, verilerin veri toplama amacına uygun sürede saklanması gibi ilkeler bulunmaktadır. Tıbbi verilerin korunmasında yasal düzenlemelerin yanında bireyi de etkinleştiren mekanizmalar yararlı olmaktadır. Bu sistemde ve $\neg$ rilerin kullanımı onaya tabidir, verilere erişimin çeşitli seviyelerde gerçek $\neg$ leşmesi kontrol altındadır, kullanıcıların kimlikleri denetim altındadır, şifreᄀleme metotları kullanılmaktadır $(2,3)$.

Bugün tıp uygulamaları sırasında özel yaşamın, mahremiyetin ya da öznelliğin korunması hakkı, kaynağını anayasalardan almaktadır. Tıp hizmetlerinden yararlanan kişilerin, kişisel nitelikteki bilgilerinin "mahremiyeti" korunmalıdır. Tutulan kayıtlar ve eldeki bilgiler, hastanın rızası olmaksızın üçüncü kişilere aktarılamaz. Kimi ülkelerde bu onamın yazılı olması istenmektedir. Bu bilgilerin adsız olarak, örneğin istatistiksel izlem, bilimsel araştırma gibi amaçlarla kullanılması ise düzenlemelere tabidir. Her bireyin özel yaşamının dokunulmazlığı hakkına saygı gösterilmeli ve bu hak korunmalıdır; bireyin düşünce, duygu ve kişisel yaşamının sırlarını, başkalarıyla ne ölçüde paylaşacağına, kendisinin karar vermesi hakkına saygı gösterilmelidir. Günümüzde, tıp kayıtlarının bilgisayarda korunması, özel sigorta kuruluşlarının yaygınlaşması ve ağırlık kazanması, sağlık kuruluşlarının bilimsel, yönetimsel, ekonomik yönden yoğun bir denetim altında bulundurulması gibi durumlar nedeniyle, hasta kayıtlarının mahremiyetinin korunması konusunda, ye- terince titizlik gösterilemeyeceği kaygısı yaygınlaşmaktadır. Bir sigorta ağına ya da bir işe girerken, yapılan tıbbi değerlendirmeler sırasında elde edilen bilgilerin korunması, en az bu taramaların kendisi kadar tartışma konusu olmaktadır.

Tıp uygulamaları sırasında, hekimin tedavisini üstlendiği hastaya ait kişisel bilgileri saklı tutma zorunluluğu, hiç kuşkusuz insan araştırmaları için de geçerli olan bir ilkedir ve araştırmaya katılan hekimlerin gönüllü katılımcının mahremiyetine (özel yaşamına) değer vermeleri ve bunun sorumluluğunu üstlenmeleri gerekmektedir. Araştırmaların sürdürülmesinde ve sonuçların yayımlanmasında gönüllülerin mahremiyetinin korunması, kişisel kimlik bilgilerinin açıklanmamasını gerektirmektedir. Bu konuda önlem olarak, örneğin kayıtların gizliliği esas alınarak veriye ulaşım sınırlandırılabilir ya da kişilere bir tanıtım numarası verilebilir.

Kişisel verilerin korunmasıyla ilgili Avrupa Birliği çerçeve yönetmeliklerinde ve özellikle biyomedikal araştırmalar açısından Oviedo Sözleşmesi (4) kapsamında çeşitli maddeler bulunmaktadır. Özellikle genetik örnek ve bilgilerin saklandığı biyobankalarda bu verilerin ayrımcılığa yol açmaması, kişilerin işveren ve sigortalar gibi üçüncü şahıslar nezdinde haklarının korunması açısından önemlidir.

\section{Insan Biyolojik Materyalinin ve Bu Materyalden Elde Edilen Kişisel Verilerin Korunması ile İlgili Etik ve Hukuki Durum}

Klinik araştırmalar alanında, multidisipliner ve uluslararası çaIışmalarda, günümüzde ve gelecekte en tartışmalı alanlardan birisi, "insan kökenli biyolojik örneklerin kullanımı” konusudur. Katılımcılardan alınmış insan kökenli biyolojik örnek ve benzeri maddelerin en yararlı biçimde kullanılmasına gösterilecek özen önemlidir. İnsanlardan araştırma için alınan örnekler; belli bir araştırma projesinde hemen kullanılmak üzere veya gelecekte öngörülen çalışmalarda kullanılmak üzere depolanmak amacıyla alınabilir. Bu iki kullanım arasında ayrım çok kesin değildir ve örneklerin bir kısmı hemen kullanılırken, kalan bölümü daha sonra kullanılmak üzere saklanabilir. İnsan kökenli biyolojik maddelerin araştırmalarda kullanılmasında etik sorunlar, iki başlıkta incelenebilir:

- Illk olarak, insan kökenli biyolojik madde ve örneklerin alınmasında, bedene müdahale edilmesini gerektiren durumlarla ilgili sorunlardır. Bu, araştırma yürütülürken yapılan müdahalelerde, kişinin bedensel bütünlüğünün riske girdiği veya aynı anda ek koruyucu önlemlerin alınması gerektiği durumlarda gündeme gelir (örneğin onam verme yeteneği olmayan kişiler).

- Ikinci olarak, alınan biyolojik örneğin kullanılmasına ve depo- 
lanarak saklanmasına ilişkin onam alınması / izin verilmesi ve elde edilen tıbbi bilginin ve verinin güvenliğinin ve gizliliğinin korunması durumudur. İkinci gruptaki sorunlar ciddi dikkat ve özen gösterilmesini gerektirir ve gerek uluslararası gerekse ulusal pek çok kurum tarafından yayımlanmış belgeler ve kılavuzlarca düzenlenmiştir.

Insan biyolojik materyalinin ve bu materyalden elde edilen verilerin kendine özgü niteliği ve ilgili tarafların menfaatlerinin farklı özellikleri nedeniyle, bu konunun hukuki açıdan da özel bir şekilde ele alınması gerekmektedir. İster biyobanka isterse de arşiv materyali olsun buralarda saklanan örneklerin nasıl alınacağından başlayarak, yapılacak her türlü işlemin yasal sınırlarının kendine özgü koşulları içerisinde çizilmiş olması ve başta katılımcı olmak üzere, tüm tarafların menfaatlerinin hukuken dengelenmiş olması gerekmektedir.

Bu konunun etik ve yasal sınırlarının çizilmesi gerekliliğinin gerekçelerine bakacak olursak;

- Örneklerin ilgilinin rızası olmadan kolayca elde edilebilmesi, - Örneklerin alınma amaçları dışında kolaylıkla kullanılabilmesi, - Elde edilen verilerin kalıcı bilgiler içermesi,

- Illgilinin hayatı için çok önemli verileri içermesi,

- İlgilinin ailesi ve ait olduğu gruba ait bilgileri içermesi,

- Verilerin ayrımcılık amacıyla kullanılma potansiyeli taşıması,

- Verilerin başkalarınca kullanımının bilimsel ve ticari olanaklar yaratması,

- Kötüye kullanılmaları durumunda kişilik haklarının zedelenmesi olasılığı.

İnsan biyolojik materyalinin ve biyolojik verilerinin güvenliği ve korunmasıyla ilgili olarak 1982 Anayasası'nın sağladığı temel anayasal güvenceler, 17. maddeyle düzenlenen kişi dokunulmazlığı, kişinin maddi ve manevi varlığını koruma ve geliştirme hakkı ile 20. maddeyle düzenlenen özel hayatın gizliliği ve korunmasıdır. İnsan biyolojik materyali üzerinde yapılacak tıbbi araştırmalar ve bunlar sonucunda elde edilecek bulguların kötüye kullanılmasının, kişinin vücut bütünlüğünü, maddi ve manevi varlığını veya kişilik haklarını zedeleme riski mevcuttur. Bu nedenle, insan genetik materyali üzerinde yapılacak saklama veya araştırma faaliyetlerinin Anayasamızın çizmiş olduğu bu çerçeve içerisinde yapılması gerekmektedir (5).

1982 Anayasası'nın 20. maddesi de, genetik araştırmalarla zedelenmesi riski bulunan özel hayatın gizliliğini güvence altına almaktadır. Bu maddeye göre; herkes, özel hayatına ve aile hayatına saygı gösterilmesini isteme hakkına sahiptir ve özel hayatın ve aile hayatının gizliliğine dokunulamaz. Bu düzenlemeye 2010 yılında bir ek yapılarak kişisel verilerin korunması ve ancak kişinin izniyle işlenebilmesi anayasal güvence altına alınmıştır. Bu düzenlemeye göre; “Herkes, kendisiyle ilgili kişisel verilerin korunmasını isteme hakkına sahiptir. Bu hak; kişinin kendisiyle ilgili kişisel veriler hakkında bilgilendirilme, bu verilere erişme, bunların düzeltilmesini veya silinmesini talep etme ve amaçları doğrultusunda kullanılıp kullanılmadığını öğrenmeyi de kapsar. Kişisel veriler, ancak kanunda öngörülen hallerde veya kişinin açık rızasıyla işlenebilir. Kişisel verilerin korunmasına ilişkin esas ve usuller kanunla düzenlenir." (5)

Anayasada yapılmış olan bu değişikliğin gerektirdiği kişisel verilerin korunmasını düzenleyen kanun (Kişisel Verilerin Korunması Kanunu, Kanun No: 6698) nihayet 24 Mart 2016 tarihinde TBMM'de kabul edilerek yasalaşmış ve 6 Nisan 2016 tarihinde yürürlüğe girmiştir (6). Bu Kanunun amacı, kişisel verilerin işlenmesinde başta özel hayatın gizliliği olmak üzere kişilerin temel hak ve özgürlüklerini korumak ve kişisel verileri işleyen gerçek ve tüzel kişilerin yükümlülükleri ile uyacakları usul ve esasları düzenlemektir (6). Gerek 6698 sayılı Veri Koruma Kanunu, gerekse sonrasında çıkarılan Kişisel Sağlık Verilerinin İşlenmesi ve Mahremiyetinin Sağlanması Hakkında Yönetmelik (7), biyotıp araştırmaları ile ilgili açık bir düzenleme getirmemiştir. Kanunda (Madde-3) "kişisel verilerin işlenmesi"ile ilgilidir; "kişisel verilerin tamamen veya kısmen otomatik olan ya da herhangi bir veri kayıt sisteminin parçası olmak kaydıyla otomatik olmayan yollarla elde edilmesi, kaydedilmesi, depolanması, muhafaza edilmesi, değiştirilmesi, yeniden düzenlenmesi, açıklanması, aktarılması, devralınması, elde edilebilir hâle getirilmesi, sınıflandırılması ya da kullanılmasının engellenmesi gibi veriler üzerinde gerçekleştirilen her türlü işlem"(6).

Kişisel veriler, ancak kullanılacak amaçla bağlantılı ve bu amacın gerekçeleriyle sınırlı olacak şekilde işlenebilir. Kişisel verilerin toplanmasından önce, bu verilerin toplanmasının amaçlarının belli olması, sonraki kullanımların da bu amaçlarla sınırlı tutulması temel ilkelerden biridir. Amaca uygun kullanım ilkesi gereğince; veri konusu kişinin rızası veya kanunun yetki verdiği haller hariç olmak üzere, kişisel verilerin toplandığı ve işlendiği amaçlar dışında kullanılmaması, elde edilebilir hale getirilmemesi veya açıklanmaması gerekmektedir.

Söz konusu kanunun yürürlüğe girmesinin ardından 20 Ekim 2016 tarihinde Kanunu'n ilk uygulama Yönetmeliği, Kişisel Sağlık Verilerinin İşlenmesi ve Mahremiyetinin Sağlanması Hakkında Yönetmelik (7) adıyla yürürlüğe girmiştir. Yönetmeliğin 4. maddesine göre "Kimliği belirli veya belirlenebilir gerçek kişiye ilişkin 
her türlü sağlık bilgisi" kişisel sağlık verisidir. Gerek söz konusu Kanun, gerekse de Yönetmelik kişisel sağlık verileri için “hassas veri" yerine "özel nitelikli veri" ifadesini kullanmıştır. Özel nitelikli kişisel verilerin, ilgilinin açık rızası olmaksızın işlenmesi yasaktır. Özel nitelikli kişisel verilerin işlenmesi süreci ile ilgili 6698 sayıIı Veri Koruma Kanununda tanımlanan Kişisel Verileri Koruma Kurulu tarafından belirlenen yeterli önlemlerin alınması şartı getirilmiştir. Ancak hangi önlemlerin alınacağı kanunda belirtilmemiştir. Ülkemiz açısından biyoetik ve insan haklarına ilişkin en önemli uluslararası ve bağlayıcı iç hukuk metni olan Avrupa Konseyi Biyotıp ve İnsan Hakları Sözleşmesi (OVIEDO) (2) başta olmak üzere ulusal sağlık mevzuatımız değerlendirildiğinde araştırmaya katılacak kişilerden aydınlatılmış onam almak hukuki bir zorunluluktur. Geçerli bir aydınlatılmış onamdan söz edebilmek için, kişiye kendisinden alınacak örneğin hangi prosedüre göre alınacağının anlatılması, kişiye örneğinin saklanacağı ve saklanacak veri tabanı hakkında temel bir bilgi verilmesi gerekmektedir. Bu bilgilerin; veri sorumlusunun kimliğini, verinin işlenme amacını, araştırmanın etik kurul izni aldığını, onamın gönüllü olduğunu ve çalışmaya katılmayı reddetmenin kişiye olumsuz sonuçlarının olmayacağını içermesi gerekmektedir

\section{İnsan Biyolojik Örneklerinin Araştırma Amaçı̆ı Kullanımı}

Avrupa'da bu alanda hukuki çerçeve, Avrupa Konseyi Oviedo Biyotıp Sözleşmesi'nde (1997) ve Konsey'in (2006) 4 numaralı İnsan Kökenli Biyolojik Maddeler hakkında Tavsiye Kararı'nda çizilmiştir (8). Sözleşme'nin 22. Maddesi (İnsan vücudundan alınmış parçalar üzerinde tasarruf; bir müdahale sırasında insan vücudunun herhangi bir parçası alındığında, çıkarılan parça, yalnızca uygun bilgi verme ve muvafakat alma usullerine uyulduğu takdirde, çıkarılma amacından başka bir amaç için saklanabilir ve kullanılabilir) katılımcılardan alınan biyolojik örneğin araştırmada belirtilen amaçlardan farklı biçimde kullanılabilmesi ve saklanabilmesi için katılımcıların özgür iradeleriyle verdikleri aydınlatılmış onamlarının alınmasını şart koşar. Ayrıca Sözleşme'nin 21. maddesinde insan vücudunun ve parçalarının maddi çıkar amacıyla kullanılamayacağını belirtir. Tüm bu düzenlemeler, bu maddelerin kullanıldığı bilimsel araştırmalardan kaynaklanan fikri mülkiyet haklarının ruhsatlandırılmasını / satılmasını engellemez ve bu durum diğer fikri mülkiyet hakları olguları ile benzer özellik gösterir. Ancak bu durum, insan kökenli biyolojik maddeler ticari amaçlarla kullanılacaklarsa, onları veren kişilerin bilgilendirilmemesi anlamına da gelmez. Aynı zamanda, araştırmacılar, yalnızca kazanç sağlamak uğruna bu maddeleri satamazlar; bu madde ve örneklerin sahipleri ticari kâr elde etme amacıyla hareket edemezler. Yalnızca harcadıkları emek ve zaman kaybı, makul düzeyde tutularak, telafi edilebilir $(4,8)$.

Avrupa Konseyi 2006 tarihli 4 numaralı Tavsiye Kararı; gelecekteki araştırmalarda kullanılmak üzere insanlardan biyolojik örnek ve madde alınması, saklanması, ileride kullanımı; toplanan insan kökenli ürünlerin depolanması ve biyobankaların yönetimi ile ilgili ilkeleri -örneğin klinik çalışmalardan, bilimsel araştırmalardan, adli tıp incelemelerinden artakalan maddelerin kullanım kuralları- gibi konuları düzenler. Tavsiye Kararı, insan kökenli biyolojik maddeler ve örnekler üzerinde araştırmaların, ancak bağımsız bilimsel ve etik kurul incelemesinin yapılarak, Biyotıp Sözleşmesi'nin ilkelerini yansıtan biçimde ve vericinin aydınlatılmış onamı alındıktan sonra gerçekleştirilebileceğini ifade eder (8). Ayrıca Araştırma Etik Kurulu incelemesinde temel bir sorun olan, biyolojik maddeler veya benzeri kişisel verilerden, katılımcının kimliğinin saptanması meselesine açıklık getirir. Genel anlamda, kimlik bilgilerine ya doğrudan dosyalarda kayıtlı kişisel veriler üzerinden ya da dolaylı olarak, araştırmacıların veya ilgili üçüncü tarafların bildikleri bir şifre ile girilebilen kayıt sisteminden ulaşılabilir. Teşhis edilemeyen maddeler, belli bir çaba gösterildikten sonra bile vericinin kimlik bilgilerine ulaşılamayan ürünlerdir. Araştırma Etik Kurulu, insan kökenli biyolojik maddelerin kullanımını içeren bir projeyi değerlendirirken, katılımcı kimlik bilgilerine erişimde ne düzeyde kalınacağının, araştırmacılar tarafından projede açıklanmış olması koşulunu arar.

Helsinki Bildirgesi (2013) Madde 32; “Biyobankalar veya benzer saklama kuruluşlarında bulunan materyal veya veriler gibi, kime ait olduğu bilinmeyen veya istenirse belirlenebilen örnek ya da verilerin kullanılacağı bir biyotıp araştırması için örnek ve verilerin alınmasından sorumlu hekim; verilerin toplanması, saklanması ve/veya yeniden kullanımı konusunda onam almalıdır. Bu onamın elde edilmesinin söz konusu araştırma için olanaksız olduğu veya pratik istisnai durumlar olabilir. Böyle durumlarda araştırma, yalnızca bir araştırma etik kurulunun değerlendirme ve onayından sonra yapılabilir" demektedir (9). "Benzer saklama koşullarında" ifadesinin arşiv materyallerine gönderme yaptığı varsayılır ise, görülmektedir ki sorumluluk, önce onamı alacak olan araştırmacı hekimin sonra da ilgili protokolü değerlendirip etik onay verecek olan etik kurulundur.

Böyle durumlar için şimdilik uygun çözüm; halen arşivde olan ve araştırmalar için kullanılmak istenen materyaller için, katılımcıların mahremiyetinin en geniş anlamda korunması, tam bir anonimizasyonun sağlanması, planlanan yeni araştırma için katılım- 
cılara tekrar aydınlatılmış onam almak üzere gidilmesinin pratik olarak mümkün olmadığının ve bunun gerekçelerinin etik kurula sunulması ve ilgili etik kurulların söz konusu araştırmalara olur vermesidir. Görüldüğü gibi bu durumda, özerklikten belirli oranda vazgeçilirken, bu sorun mahremiyet ve veri güvenliğinin artırılmasıyla dengelenmeye çalışılmaktadır.

Araştırma Etik Kurulu, insan kökenli biyolojik madde koleksiyonu veya biyobankalar kurulması ile ilgili proje önerisi kendilerine sunulduğunda bu noktaları dikkatle incelemelidir: Başvuru projesinde, öncelikle, güvenilir bir denetim mekanizması oluşturulmuş olmalıdır; biyolojik örnekler ve maddelere araştırma amaçlı olarak erişimi düzenleyen kurallar saydam ve açık biçimde ifade edilmiş olmalıdır.

6698 sayılı Veri Koruma Kanunu ve ilgili Yönetmelik değerlendirildiğinde, hassas verilerin işlenmesi aşamalarında alınacak yeterli önlemlerin neler olduğu, biyometrik genetik veriler gibi ekstra koruma gerektiren verilerin biyotıp araştırmaları özelinde nasıl işleneceği ve alınan biyolojik materyal/verilerin daha sonraki araştırmalarda yeniden kullanılıp kullanılmayacağının düzenlenmediği görülmüştür. Ayrıca, $A B$ düzenlemelerinde olduğu gibi veri güvenliği için kodlama yöntemlerine ilişkin bir düzenlemeye de rastlanmamıştır. İlgili literatürde tanımlanmış olan açık onam (open consent) türünün gerek 6698 sayılı Veri Koruma Kanunu gerekse Yönetmelik'te biyotıp araştırmaları açısından bir karşılığının olmaması da bir sorun olarak karşımıza çıkmaktadır. İlgili onam belgelerinin nasıl düzenleneceğinin açık ve net biçimde tanımlanmasına ve uygulamaya sokulmasına gereksinim vardır.

Ülkemizde de konu ile ilgili tüm tarafların (arşiv materyalinin/ biyobankaların ilgili tarafları) hak ve sorumluluklarının tanımlandığı yol gösterici rehberler hazırlanmaktadır. Bunlardan bir tanesi de HÜ Biyoetik Merkezi (HÜBAM) ve HÜ Biyolojik Kaynak Bankası ve Genombilim Uygulama ve Araştırma Merkezi (HÜBiGEM) tarafından bir çalıştay sonrası hazırlanmış ve hem araştırmacıların hem de etik kurulların kullanımına sunulmuştur (10).

\section{Konu İle İlgili Onam Formları}

Bir biyobankada ya da arşiv materyali olarak bireysel ya da kurumsal olarak depolanan ve araştırmalarda kullanılmayı bekleyen insan biyolojik materyalleri için gereklilikleri yukarıda tanımladık. Burada geçerliliği olan 2 onam türünden söz edilebilinir;

- Kademeli (çok seçenekli) Onam ve

- Geniş/Boş onam (Etik Kurulun kabul etmesi koşuluyla) kullanılabilir.

Herhangi bir nedenle elinde kurumsal ya da kişisel bir biyolojik materyal arşivi olan herhangi bir araştırmacı, bu arşiv materyalini kullanarak bir araştırma projesi planladığında; şimdilik uygun çözüm, halen arşivde olan ve araştırmalar için kullanılmak istenen materyaller için, katılımcıların mahremiyetinin en geniş anlamda korunması, tam bir anonimleştirmenin yapılması yani biyolojik materyal ile kişi bağlantısının yeniden kurulamayacak şekilde kesildiğinin güvencesinin beyan edilmesi, planlanan yeni araştırma için katılımcılara tekrar aydınlatılmış onam almak üzere gidilmesinin pratik olarak mümkün olmadığının ya da olanaksız olduğunun araştırmacı tarafından beyanı ve bunun gerekçelerinin etik kurula proje protokolünde sunulması ve ilgili etik kurulların da söz konusu araştırmalara Helsinki Bildirgesi (2013) Madde 32'ye dayanarak, olur vermesidir.

Görüldüğü gibi aksi durumda atık biyolojik materyal olacak materyal araştırma sonucunda elde edilmesi olası yarar gözetilerek, materyal vericisinin özerkliğinden belirli oranda vazgeçilerek ve bu vazgeçiş hem yararlılık hem de mahremiyet ve veri güvenliğinin arttırılmasıyla dengelenmeye çalışılarak mevcut durum etik açıdan haklı çıkarılabilir.. Ancak başta da ifade ettiğimiz gibi ilgili etik kurulun bilgilendirilmesi ve araştırmacı yazılı beyanına dayalı olarak vereceği etik kurul onayı şarttır.

Hastadan şimdi alınacak ve arşiv materyali olarak saklanması planlanan her tür biyolojik materyal için, ister tanı/tedavi amaçlı, isterse araştırma amaçlı alınmış olsun, onam formu alınmalıdır ve onam formuna aşağıdaki olasılıklar eklenmelidir (KADEMELI ONAM);

- Biyolojik materyalimin yalnızca tanı amaçlı kullanımına izin veriyorum.

- Biyolojik materyalimin.................. (belli bir nedenle) kullanılmasına izin veriyorum / vermiyorum.

- Sadece kimliksizleştirilmiş kullanımına izin veriyorum.

- Ek bir bilgilendirme gerekmeden .................. belli tip araştırmalarda kullanımına izin veriyorum

- Tekrar onam alınmak kaydıyla araştırmalarda kullanımına izin veriyorum.

- Her çeşit araştırmada kullanılmasına izin veriyorum (GENiş ONAM)

\section{Sonuç ve Öneriler}

İnsan biyolojik materyali ve verilerinin elde edilmesi/saklanması/işlenmesi, erişimi süreçlerinde bilimsel geçerlilik ve güvenilirliğin sağlanması, bu açıdan da kalite güvence sistemlerinin etkin kullanılması etik bir gerekliliktir. Her bir basamakta uyulması gerekli bilimsel, teknolojik, etik gereklilikler çerçeve kurallar şeklinde tanımlanmalıdır. Örneklerin saklanmasındaki 
teknik olanakların gelişiminin yanı sıra, biyolojik verilerin dijital ortamda işlenebilmesi ve bilgisayar teknolojilerindeki yenilikler de örneklere ait verilerin toplanmasını, izlenmesini ve üzerinde her türlü analizin yapılmasını günümüzde kolaylaştırmaktadır.

Ülkemiz açısından biyoetik ve insan haklarına ilişkin en önemli uluslararası ve bağlayıcı iç hukuk metni olan Avrupa Konseyi Biyotıp ve İnsan Hakları Sözleşmesi (OVIEDO) başta olmak üzere ulusal sağlık mevzuatımız değerlendirildiğinde araştırmaya katılacak kişilerden aydınlatılmış onam almak hukuki bir zorunluluktur (11). Hiçbir kişisel çıkar veya maddi teşvik olmaksızın, girişimsel ya da girişimsel olmayan yöntemler yoluyla elde edilen insan biyolojik materyalinin araştırmacılar, kamu ya da özel kurumlar tarafından toplanması, işlenmesi, kullanımları ve saklanmaları için özgür, aydınlatılmış ve amaca yönelik onam alınmalıdır.

Planlanan her bir yeni araştırma için katılımcılara tekrar aydınlatılmış onam almak üzere gidilmesi gerekmekle beraber, bu durum sıklıkla hastalarda kafa karışıklığına yol açmakta, bunun yanı sıra, zaman alıcı, pahalı ve pratik olmayan bir yol olmaktadır. Katılımcılara tekrar başvurulması kişilerin özerkliklerine saygı açısından en uygun etik yaklaşım gibi görünmekle beraber, sıklıkla olanaksızdır. Bu nedenle önerilen "geniş onam" ya da "kademeli onam" dır (11).

Araştırma dünyası önemli değişikliklere gebe görünmektedir; bu değişiklikler arasında, yeni gelişmiş genetik ve genomik teknolojilerin geliştirilmesi, büyük miktarda genotipik ve fenotipik veri içeren veri tabanlarının çoğalması ve hem ulusal hem de uluslararası düzeyde birçok kurum arasında geniş çapIı veri paylaşımının gerçekleşmesi yer almaktadır. Bu değişiklikler, biyogüvenlik konusunda da, araştırma katılımcılarının en iyi nasıl korunacakları konusunda, yeni sorular sorulmasına yol açmaktadır. Bu sorulara cevaben, biyobankacılığın yasal, etik ve sosyal konularına yönelik en iyi uygulama örneklerinin geliştirilmesine gereksinim vardır. Biyobankacılığa ilişkin yeni etik kuralların yanı sıra, gizlilik ve insan hakları korumalarına ilişkin yeni düzenlemelere de gereksinim bulunmaktadır.

Bilim ve araştırma ortamındaki değişiklikler, büyük veri araştırmaları, ticari kullanım ve mülkiyet konuları için kullanılabilecek en uygun onam modelleri hakkında tartışmalar devam etmektedir(12).

Biyobankalama ile ilgili etik, yasal ve sosyal konuları tartıştığı makalesinde Bledsoe, bireylerin biyolojik örneklerinde sahip oldukları hakların açıklığa kavuşturulmasının önemli olduğunu ifade ederek, bazı hasta ve hasta savunucularının biyolojik örneklerle ilgili haklarını dile getiren ve "biyohak" hareketi olarak da adlandırılan yakın tarihli bir hareketten söz etmektedir
(12). Biyohak bağlamında dile getirilen sorular, yukarıda tartıştığımız sorunlarla aynıdır; araştırma örneklerini sunan bireyler, bu örneklerin araştırmada nasıl kullanıldıklarını ve araştırma bulgularından elde edilen karlardan yararlanma konusunda ne tür haklara sahip olmalıdır? Bireyler biyolojik örneklerinin araştırmada nasıl kullanılacağı konusunda ne kadar kontrol sahibi olmalıdır? Böyle bir "biyohak" ile ilgili pratik düşünceler ve sınırlamalar nelerdir? Özerklik hakları, araştırmalarda insan örneklerinin kullanımından kaynaklanan toplumsal faydalarla en iyi nasıl dengelenmelidir?

Araştırma amaçlı sağlık veri tabanlarının ve biyobankaların oluşturulmasının, bağımsız etik kurullar tarafından onaylanması önemlidir. Buna ek olarak etik kurul verilerin ve biyolojik materyalin kullanılmasını da onaylamalı, verilerin ve materyalin toplanması sırasında verilmiş olan onamın planlanmış kullanım açısından yeterli olup olmadığını kontrol etmeli, bağışçıyı (veri sahibi) koruma açısından başka önlemlere de gerek olup olmadığını belirlemelidir. Etik kurul, bu alanda sürmekte olan etkinlikleri izleme hakkına da sahip olmalıdır. İnsanlardan elde edilen ve kime ait olduğu belirlenebilen materyal veya veriler üzerinde yapılan araştırmalar da dahil olmak üzere, gönüllülerin yer aldığı tıbbi araştırmalar için etik ilkeleri belirleyen Helsinki Bildirgesi'nin 23. Maddesi, etik kurulun sürdürülmekte olan çalışmaları izleme hakkını ifade etmektedir. Toplumsal güvenin inşa edilmesi biyobanka araştırmalarına katılımın sağlanması açısından çok önemlidir. Bu nedenle güvenli veri koruma ortamı ve mekanizmalarının kurulmasının yanı sıra araştırmaya katılan gönüllülere hangi verilerinin, kim tarafından ne amaçla kullanıldığının açık, anlaşılır ve şeffaf bir şekilde anlatılması gerekmektedir, bunun denetimi de Etik Kurullara verilmiştir. Bağımsız etik kurulların, kişilerin özel hayatının gizliliğinin korunması ile, araştırmaların yürütülebilmesi için gerekli olan verilerin kullanımı arasında, bir denge kurulup kurulmadığını her araştırma özelinde, araştırmanın doğası ve şartlarına göre değerlendirmesi önemlidir.

\section{Çıkar çatışması / finansal destek beyanı}

Bu yazıdaki hiçbir yazarın herhangi bir çıkar çatışması yoktur. Yazının herhangi bir finansal desteği yoktur.

\section{Kaynaklar}

1. Nishardi Wijeratne and Solomon R Benatar, Ethical issues in laboratory medicine, J Clin Pathol 2010, 63: 97-98.

2. Büken N. Opinions about the future of Clinical Trial in Turkey, Journal of Clinical and Experimental Investigations, JCEI 2016; 7: 258-64. 
3. Buken NO. Clinical trial ethics in Turkey in the context of some expectations and predictions. Int J Clin Trials 2016; 3: 180-186.

4. The Convention for the Protection of Human Rights and Dignity of the Human Being with regard to the Application of Biology and Medicine: Convention on Human Rights and Biomedicine (ETS No 164) was opened for signature on 4 April 1997 in Oviedo (Spain).

5. Uzeltürk, S. 1982 Anayasası ve İnsan Hakları Avrupa Sözleşmesine Göre Özel Hayatın Gizliliği Hakkı, İstanbul: Beta Yayıncılık, 2004.

6. 24/3/2016 tarih ve 6698 sayılı Kişisel Verilerin Korunması Kanunu; c2016 (cited 2016 April 25). Available from: http://www. resmigazete.gov.tr/main.aspx?home=http://www.resmigazete. gov.tr/eskiler/2016/04/20160407.htm\&main=http://www.resmigazete.gov.tr/eskiler/2016/04/20160407.htm.

7. 20 Ekim 2016 Tarih ve 29863 Sayılı Kişisel Sağlık Verilerinin İşlenmesi ve Mahremiyetinin Sağlanması Hakkında Yönetmelik.

8. COUNCIL OF EUROPE COMMITTEE OF MINISTERS, Recommendation Rec (2006) 4 of the Committee of Ministers to member states on research on biological materials of human origin Adopted by the Committee of Ministers on 15 March 2006 at the 958th meeting of the Ministers' Deputies
9. World Medical Association. Helsinki Declaration. World Medical Association; c2017 (cited: 14.12.2017). Avaible from: http:// www.wma.net.

10. HÜ Biyoetik Merkezi, Araştırma Biyobankacılığı Rehberi, 2016 (cited 2016 Feb). Avaible from: http://www.hubam.hacettepe.edu. tr/ekler/pdf/biyobanka/arastirma_biyobanka_rehber.pdf

11. Ünsal Ç.Z., Büken N.Ö. 'Biyotıp araştırmaları ile ilgili olarak, "kişisel verilerin korunması kanunu" ve "kişisel sağlık verilerinin işlenmesi ve mahremiyetinin sağlanması hakkında yönetmelik" ne diyor?. Türkiye Klinikleri 2018; 82-90.

12. Bledsoe Marianna J. Ethical legal and social Issues of biobanking: past, present, and future" Biopreservation and Biobanking 2017;5:2 